\title{
Research on Necessity for Development of North Pole Northeast
}

\author{
Passage \\ Shuping $\mathrm{Gao}^{1, a}$ Wanzheng $\mathrm{Ai}^{2, \mathrm{~b}}$ Honggang Zhang ${ }^{3, \mathrm{c}}$ \\ ${ }^{1}$ Marine College of Zhejiang Ocean University, Zhoushan 316000, P. R. China \\ ${ }^{2}$ Marine College of Zhejiang Ocean University, Zhoushan 316000, P. R. China

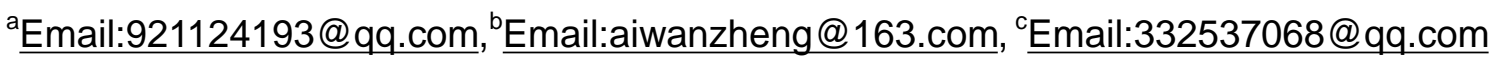

Keyword: Northeast course; navigation; safety; advantage; necessity

Abstract: With global warming of climate, melting of sea ice in polar region makes navigation in north pole course having been sealed by ice and snow possible. Meanwhile, north pole region gradually becomes a battleground for military and economy between north countries, the mystery of north pole northeast course famed as one of golden courses is also unveiled. Starting from development of ocean economy of our country, this paper discusses necessity for development of north pole northeast course and problems to be resolved.

\section{Preface}

Quick melting of sea ice in north pole region makes navigation in northeast course possible, as one of three northern sea-routes, north pole northeast course is a new course from China to Europe, with many advantages, also with certain difficulties, so it is necessary for us to further research its seaworthiness, providing reference for future navigation of Chinese ships in the maritime space and for people to know northeast course. Before that, scholars and experts at home and abroad have conducted many similar researches. They recorded specific situation of northeast course through site investigation or by following navigation of ships, and these records provide convenience for our further research, but they still have deficiency in comprehensive, specific analysis. To compensate these defects, we research the seaworthiness of northeast course by summarizing materials of predecessors, using data statistics, analysis and calculation.

\section{Summary of north pole northeast course}

Report on Assessment of North Pole Navigation 2009 defined northeast course as the route starting from Bering Strait, reaching Norway north corner along Eurasia and north coast of Siberia [1-2]. Geographically, northeast course passes through Barents Sea, Kara Strait, Rapp Jeff Sea, east Siberia and Chukchi Sea, five maritime spaces of the Arctic Ocean. There are many straits along the route, most of which is very narrow. This has become an important factor influencing navigation of ship. Entering Kara Strait from Barents Sea needs to pass through Gorski Schall Strait at south Waygachi Island. The strait is about 37 to $45 \mathrm{~km}$ long, 3 to $15 \mathrm{~km}$ wide, only $2.5 \mathrm{~km}$ at the narrowest point, $20 \mathrm{~m}$ deep, it has been constructed to a perfect transportation system. The Saucareski strait north to Villekieski Sea about $112 \mathrm{~km}$ wide, about $50 \mathrm{~km}$ at the narrowest point, 
about 45m deep, is the second strait entering Rapp Jeff Sea from Kara Sea, Dmitri Laptev Strait located at east section of "northeast course", is the southernmost course of New Siberia Islands and inland Russia connecting Rapp Jeff Sea and East Siberia Sea. The strait is about $120 \mathrm{~km}$ long, 13 to $17 \mathrm{~m}$ deep, water depth in the east is less than $10 \mathrm{~m}$, only ships with draft no more than $6.5 \mathrm{~m}$ can pass. Sonny Bay is the second strait connecting Rapp Jeff Strait and Siberia Strait, crossing New Siberia Islands, about $402 \mathrm{~km}$ long, $15 \mathrm{~m}$ deep at the shallowest point. Deran Strait connecting East Siberia Sea and Chukchi Sea separates Wrangel Island from inland Russia, about $230 \mathrm{~km}$ long along south coast, minimum $15 \mathrm{~m}$ deep, about $350 \mathrm{~km}$ long along north coast, minimum $45 \mathrm{~m}$ deep.

\section{Development need of the situation of maritime transportation of our country}

Chinese traditional maritime courses have many problems, so China expects to develop new courses. Middle east region is the main oil export place, oil import of China also relies on Middle East. Oil transportation from Middle East to China needs to pass through Hormuz Strait, India Ocean course and the Strait of Malacca. Looking forward at future Chinese economy, demand for oil will increase continuously, and most will still rely on import from Middle East. So the importance of the oil transportation lifeline is very obvious ${ }^{[3-4]}$. But in recent years, the course appears unsmooth. Main problems are shown in the following aspects:

\section{(1) Malacca dilemma}

In recent years, news on terrorist attack across the world is heard commonly, and terrorist attack also threats Malacca Strait. If Malacca is attacked or controlled, it is similar to the "throat" of China and southeast Asia countries being gripped, dramatically impacting Chinese economy. In addition, channel treatment issue and constant huge transportation volume result in sedimentation of both coasts. If the treatment issue cannot be perfected blockage of channel, even closure of channel will be resulted, which will influence global economy greatly. Furthermore, with continuous rise of oil demand, oil transportation of China will rely on Malacca Strait more heavily. It is predicted that by 2040 oil demand of China will reach 700 million tons, and imported oil will reach 400 to 700 million tons, above $2 / 3$ relies on import. These figures show that as an important passage for imported oil of China Malacca shall not be imposed any threat.

\section{(2) Rampant piracy in India Ocean}

In recent years, on India Ocean courses, pirate activity is very rampant. They recklessly claim ransom, rob goods, seriously threating safety of ships passing the sea area. Pirate activity results in exponential increase of premium paid by ships passing this section of course. So far, cargo ships of many countries have been hijacked by pirates here. On October 19, 2009 the Chinese cargo ship Dexinhai was hijacked on the course from South Africa to India and was rescued after more than two months. Considering increasingly frequent pirate activity, various countries used the methods of forced rescue and pay ransom, meanwhile warships of various countries form a united escort fleet to protect safe navigation of ships. But such method spends huge expense, and cannot totally guarantee the safety of every ship. Incidents of pirate hijacking ship still happen constantly.

\section{(3) Complicated South China Sea issue}

Islands in South China Sea have been inherent territory of China since the ancient times, but in recent years disputes between southeast Asian countries and China upgrades constantly, especially in Nansha Islands, part of islands and islets are controlled by Vietnam and Philippines. So the strategic position of South China Sea is apparent. Once South China Sea issue upgrades, maritime 
transportation of our country will be hindered, going against our maritime transportation. So in critical war period, it is necessary for our country to make maritime transportation steer clear of South China Sea and develop new courses.

\section{North pole northeast course has development potential}

\section{(1) Feasibility in political geography}

Most of north pole northeast course is within the control range of Russia, while Russia is our friendly country, with close political and economic relation with our country. The north course called by Russia (located in the Arctic Ocean, connecting Russia, Europe and part of ports in far east, from Kara Strait to Provideniya Bay, about 5,500 km long) is an import part of Northeast course. Russia attributes north course to its inner se ${ }^{[5-6]}$.There is less ice in northeast course from July to November, with the condition of navigation, which is the most mature north pole course. Russia made Rules on Navigation in North Course Waters, specifying the time of navigation, ice class of navigating ships and auxiliary measures in northeast course. Northeast course can dramatically shorten the voyage from Europe to Pacific Ocean, and can also avoid safety threat from regions such as India Ocean, the Strait of Malacca, Somalia, Aden Gulf, with both practical commercial interest and long term strategic significance. According to statistics from related departments of Russia, ships passing through northeast course every summer show rising trend.

\section{(2) Helpful to save cost}

Currently there are two courses from China to Europe including Suez Canal course and the Cape of Good Hope course. If north pole northeast course is opened, it will become a new "Atlantic-Pacific" axis course. Current oceanic course from Asia to Europe is about 13,500 nautical mile, after "northeast course" is opened it can be shortened to 8,500 nautical miles, decreasing by about $35 \%$. The most direct profit brought to ship operator by shortening of course is to reduce fuel cost. The largest part of transportation cost is fuel cost, about $50 \%$ of navigation cost. According to investigation report, during navigation in typical sea area, fuel consumption of ships is 0.4 ton/nautical mile, because there is more floating ice in more than 800 nautical mile sea area of "northeast course", fuel consumption during navigation in the sea area is estimated above 0.6 ton/nautical mile. From Shanghai to Rotterdam, single voyage of navigation in "northeast course" consumes about 2,370 tons fuel (loading and unloading goods along the route spends about 7 days, consumes fuel about 12 ton/day), navigation through Suez Canal consumes about 3240.5 tons fuel. According to the latest fuel price on March 10, 2017, Singapore IFO380 is $650 \mathrm{USD} /$ ton, MGO is $980 \mathrm{USD} /$ ton. According to experience in navigation, diesel oil expense is about $1.5 \%$ fuel expense. In a word, total fuel cost for single voyage through Suez is about 2147,267 USDs, while that through "northeast course" is only 1541,242 USDs, only the cost of fuel will save 581,245 USDs in a single voyage.

\section{(3) Helpful to lift geopolitical position of our country}

Because the glacier always covering the Arctic hinders the maritime passage of direct communication between China and north pole countries. Except that China and Russia contact and communicate closely, economic and commercial intercourse between China and other north pole countries is not close. Economic and efficient northeast course must closely connect every aspect such as politics and economy between north pole countries. As second largest economy in the world, China's international position continuously rises, with extensive development prospect in economic 
and political cooperation with north pole countries. Both side have complementary interest appeal in many aspects. Deepening cooperation with every north pole country is the premise and guarantee of China participating in north pole affair, reducing friction force and drag force for China to conduct related activity in north pole, so as to smoothly carry out our maritime power strategy, lift international political position.

\section{(4) Helpful for economic development of our northeast region}

Our northeast is very close to north pole region. Active use of north pole northeast course can give full play to resource advantage and geographic advantage of our northeast region to strengthen contact of northeast region with outside, invigorate economy of northeast region, realize real rejuvenation of northeast old industrial base. The estuary of Tumenjiang River is close to our northeast region, directly connecting north pole northeast course, enabling it to become the optimum starting point to north America and Europe, resolve the economic development and transportation problem always troubling northeast region by constructing Tumenjiang estuary. Meanwhile, there are many rivers in northeast region, by connecting northeast course, the water system in our northeast region can be connected to form an united transportation network.

\section{Problems to be resolved in development of north pole northeast course}

\section{(1) Course treatment and navigation service issue}

There is much ice and snow, sea ice in north pole region reflecting and refracting sunlight, which is the main cause that sea ice cannot melt completely, resulting that whole sea is covered with sea ice in north pole in winter, even in midsummer, much floating ice still floats, fractures and melts. So north pole northeast course needs to be further dredged and planned to further optimize navigation condition. Meanwhile, it is also necessary to carry out traffic control service, provide instruction and help for ships difficult to manipulate.

\section{(2) Navigation law issue}

Russia thinks northeast course is in its inner water scope, and controls the waters by making related legal institution and regulations, charging ships entering the course for service and traffic. But there is always legal divergence over whether north pole northeast course belongs to international waters. Internationally more voice thinks that northeast course belongs to international strait, it shall apply to transit traffic institution according to international regulations, without being unilaterally managed and controlled by any country. For politics manipulator, northeast course not only has political temptation, they more concern the geographic issue brought by it, development of northeast course probably influences the change future world structure. If China plans to participate in north pole affair, it needs to consider legal issue involved by above two different proposals.

\section{Conclusion}

Like a mysterious treasure box, north pole northeast course will remove the veil of ice and snow, showing humankind infinite surprise and temptation. Though currently development institution of northeast course is not perfect yet, some problems are to be resolved, in terms of either geographic location, condition of navigation, or political effect, development of north pole northeast course has more advantages than disadvantages, China shall develop north pole northeast 
course vigorously to promote rise of national position.

\section{Reference}

[1] Qinglei Guan, Peiqing Guo. Overlook North Course (first volume) [J] Ocean World,2008,10 (6) :11-12

[2] Zhen Li, Maixiu Hu, Summary of Research on Potential Economic Strategic Value of North Pole Course, [J] Oceanic Economy ， 2015,8(23):23-24

[3] Tao Lu. Why Chinese Merchant Ships Step Back from North Pole Course [J] China Ocean Newspaper, 2015, 5(16):31-32.

[4] Kuang Liu, Yuetong Xu. SWOT Analysis of China North Pole Northeast Course [D].2013, 20-21.

[5] Yuxi Cao, Ran Dai, Preliminary Research on Feasibility of Navigation in Arctic [D]2010, 10 -11 .

[6] Baogang Lv, Yongning Zhang, Essence of South China Sea Issue Is Fight for Energy [J], Nanhai Economy,2011,2(10): 12-13. 